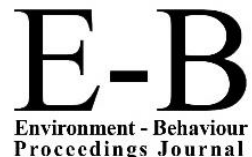

Environment - Behaviour
Procecdings Journal
AIVCE-BS-2, 2020ShahAlam

https://www.amerabra.org; https://fspu.uitm.edu.my/cebs; https://www.emasemasresources.com/ AMEABRA International Virtual Conference on Environment-Bahaviour Studies, $2^{\text {nd }}$ Series

cE-Bs, FSPU, Universiti Teknologi MARA, Shah Alam, 02-03 Dec 2020

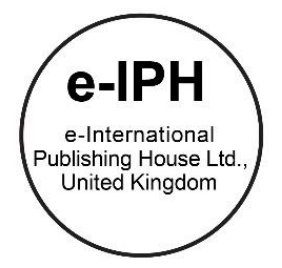

\title{
Ergonomics Concept in Inclusive Public Playground Targeting on Children with Disabilities
}

\author{
Nurul Asyikin Mohd Radzi ${ }^{1}$, Kharizam Ismail2, Lilawati Ab Wahab³, \\ ${ }^{1}$ Faculty of Architecture, Planning and Surveying, Universiti Teknologi MARA, Shah Alam, MALAYSIA \\ 23 Faculty of Architecture, Planning and Surveying, Universiti Teknologi MARA, Perak Branch, Seri Iskandar MALAYSIA \\ nurulasyikinradzi@gmail.com ${ }^{1}$ khari511@perak.uitm.edu.my ${ }^{2}$ lilawati@perak.uitm.edu.my ${ }^{3}$ \\ Tel of 1st Author: +6012 5484902
}

\begin{abstract}
Nowadays, playgrounds are underused to improve the physical and social development of young children with special needs. Therefore, this study aims to identify the key criteria of ergonomic inclusive public children playground aim for children with disabilities (CWDs). The study explored the process of universal design and the ergonomics function of play equipment that focuses on CWDs through physical site observation and interview protocol done among caregivers, parents of children with disabilities, and all stakeholders involved in the development of the public playground in Malaysia. The result presents three major themes as a guideline to create an ergonomic inclusive playground.
\end{abstract}

Keywords: Ergonomics; Universal Design; Public Playground; Children with disabilities.

eISSN: 2398-4287@ 2020. The Authors. Published for AMER ABRA cE-Bs by e-International Publishing House, Ltd., UK. This is an open-access article under the CC BY NC-ND license (http://creativecommons.org/licenses/by-nc-nd/4.0/). Peer-review under responsibility of AMER (Association of Malaysian Environment-Behaviour Researchers), ABRA (Association of Behavioural Researchers on Asians) and cE-Bs (Centre for Environment-Behaviour Studies), Faculty of Architecture, Planning \& Surveying, Universiti Teknologi MARA, Malaysia.

DOI: https://doi.org/10.21834/ebpj.v5i15.2499

\subsection{Introduction}

A human being is designed to enjoy things that advance the development of his brain, and this naturally causes humans to seek sensations that help to organize the mind. This is one reason why play is crucial for children's development in the sense of affective, psychomotor, cognitive, social interaction and creativity (Saral, 2016). Realizing the importance of play, playground, playpark, or play area has been built widely all around the world since the nineteen century to support the play of the children specifically.

However, despite the fact that the playground is designed to support the play of children, CWDs are frequently incapable of fully participating in play on playgrounds (Soltani, Abbas and Awang, 2012). According to Md. Saaid, (2016) public playgrounds in Malaysia have not changed much in the previous 20 years in terms of function and design. Numerous parks and playgrounds in Malaysia lack accessible structure, which decreases the opportunity for participation and activities by children with disabilities. Apart from that, not to mention accessibility, but some of the available public playgrounds can be hazardous to children with disabilities when safety is ignored.

According to the Social Welfare Department (2019), the figure of 549,554 registered children and adults with disabilities is a gross underestimate. Parents who are embarrassed having disabled children (OKU) may be reluctant to register their children under the Social Welfare Department, and it is estimated amongst 29 million populations of Malaysia, there were 900,000 children who less than 15 years old with different disabilities, need special care and facilities in public areas (Malaysia Kini, 2019). Besides, a recent survey by UNICEF (2018) showed that about only $1 \%$ of the country's playgrounds are built with the intent to accessible for children with disabilities. In other words, by not having access to playgrounds, children with disabilities can be denied to both chances to be in physical and social environment exist on a playground.

eISSN: 2398-4287@ 2020. The Authors. Published for AMER ABRA cE-Bsby e-International Publishing House, Ltd., UK. This is an open access article under the CC BYNC-ND license (http://creativecommons.org/licenses/by-nc-nd/4.0/). Peer-review under responsibility of AMER (Association of Malaysian Environment-Behaviour Researchers), ABRA (Association of Behavioural Researchers on Asians) and cE-Bs (Centre for Environment-Behaviour Studies), Faculty of Architecture, Planning \& Surveying, UniversitiTeknologi MARA, Malaysia.

DOI: https://doi.org/10.21834/ebpj.v5i15.2499 
Besides, in making an inclusive environment, ergonomic approach for children with disabilities becomes essential. The children's playground equipment ought to be designed ergonomically to fit the shape and dimension of the child's hand and other parts of the body to eliminate risk and difficulties for them to use, especially for CWDs. This is crucial because, according to Shea and Boyle, (2017), approximately $75 \%$ of playground-related injuries occur at the public playground and climbing equipment is the most common source of children's injuries.

Therefore, under Persons with Disabilities Act2008 (Act865) (PWDA) in line with the 11th Malaysia Plan, which stressed the person with disabilities' same right to access and use public facilities, amenities, services and buildings, this study endeavours to make inclusive the concept of ergonomics and UD in the current public playground to support every child's development. In all fairness, every child, including children with disabilities, would have the same right to play.

\subsection{Aim and Objective}

This article aims to identify the key criteria of ergonomic inclusive public children playground aim for children with disabilities (CWDs). The objectives of the study are set as follows:

i. To identify the suitability of the current condition of the public playground for disabled children in term of UD and ergonomics principle.

ii. To identify the criteria needed to build an ergonomics inclusive playground aimed for children with disabilities in Malaysia.

\subsection{Literature Review}

\subsection{Current CWD's use of public playground}

Although the play is a widely studied component of child development and early childhood education, children's behaviour on outdoor playgrounds, especially for CWDs, have been given scant empirical attention. According to Ayatac (2017), even if these children managed to reach public playgrounds, they are not adequately welcome to play as the equipment provided does not support their special needs. The playground that can meet their special needs is scarce in number. Besides, in a study by Fernelius, (2017), interviewing the children with disabilities felt that they have felt excluded at the playground, often feeling like spectators, watching other kids play and interact but not able to participate themselves. These children with disabilities feel this absence of inclusion on playground was due to their decreased ability to utilize the available equipment and materials. In addition, these children also missed their valuable play experience due to the parent's fears on safety and injury and this directly pose limitation on children with disabilities' participation in the playground.

On another point of view, many researchers also agreed that's the exclusion does not only happen to children with disabilities due to their limit access to the equipment, but they also faced social exclusion as these disabled children are 'essentially' different from normal children (Clarke, 2006; Connors and Stalker, 2007). This is proved in a study by Jing,(2019), who found that there are only a few numbers of non-disabled children willing to interact and communicate with children with disabilities. The absence of socio-spatial features in the playground also places barriers for these children with disabilities to develop peer interaction.

Apart from that, Feeney and Galer,(2007) mentioned that people with disabilities, especially those with physical impairment, differ in capacity and characteristic, requiring special arrangements. This results in the numerous play equipment available on the market to enable CWDs to use standard play equipment designed for normal children. The fear of lack of safety in playgrounds also causes many parents to limit their children's activities. This parental fear about play safety is greater among disabled parents as children with disabilities are more sensitive and require extra attention. As a result, the children miss out on essential developmental experiences without exposure to opportunities for play.

\subsection{Inclusion of children with disabilities through Universal Design (UD) concept}

Playing in community settings is a way for children with disabilities to gain a sense of belonging and a sense of community identity. Thus, integrating the UD concept in the public playground is vital to supports the idea that all children have the right to play, as mentioned in Article 31 of the Convention on the Rights of the Child 1989. This UD concept is defined by its pioneer Follette et al., (1998) as a term referring to designing all products and environment in an inconspicuous manner to be both aesthetic and usable to the best degree conceivable by everybody, regardless of their age, ability or status in life. Universal design is not a design style but a principle used to ensure everyone can enjoy the product or environment without the need for adaptation or specialized design. This universal design concept combines accessibility, versatility, inclusivity, and freedom from the barriers to permit all degree of sensory awareness, a wide range of movements, and physical and intellectual functions (Jafari, 2014).

\subsection{Ergonomics in Play Equipment}

The well-known authors' viewpoints in different fields tell us the value of play equipment in children's physiology and physical development (Robertson, 1995; Ginsburg, 2007; Park, 2010). According to Tosi, (2019), universal design is a branch of ergonomics 
and a user-centred design. While universal design approach aimed at providing mainstream goods and/ or services available to and usable by people with the widest range of abilities in the widest range of circumstances without any adaptation or design criteria, ergonomics in this circumstance aimed to provide a design of playground equipment which fit the users ergonomically, both physical and cognitively to ensure that the playground is ideal for children's capability (Edward Elton, 2015; Gonzalez and Certucha, 2019). Thus, in creating a living environment and well-being services, it is crucial to consider both elements.

However, while many modern toy companies worldwide emphasize the cutting-edge design in their product, the product's ergonomics feature is sometimes neglected. According to Grozdanovic et al., (2013), modern play equipment ought to be ergonomically designed to fit the current development of children.

Etymologically, the word ergonomics was derived from the Greek words which refer to the scientific discipline concerned with the understanding and application to the theory, concepts, data and design methods of the relationships between humans and other elements of a system to maximize human health and system overall efficiency (Robertson, 1995). In simpler words, ergonomics means knowledge about body size and muscular capabilities, which crucial for proper human factor design. The study of ergonomics is essential to the design and appraisal of tasks, jobs, products, environments, and systems to meet people's needs, abilities, and limitations (Adawiyah, 2018). According to Stratton, (2000), ergonomics experts have emphasized that ergonomics for children is different from adults, and it should be designed appropriately with children's bodies to avoid any hazards or injuries.

\subsection{Designing playground for all children}

Designing a playground for all types of abilities can be a complex task. Keeping the balance between accessibility, safety and fun without losing a creative solution was the biggest challenge. The tables below summarize the key criteria of inclusive and ergonomics playground found in the literature review.

Table 1: Universal Design Principle

\begin{tabular}{|l|l|}
\hline \multicolumn{2}{|l|}{ Seven Universal Design Principle } \\
\hline Equitable use & $\begin{array}{l}\text { The design of the playground is useful for children with diverse abilities. The design should be able } \\
\text { to offers various features for different user. }\end{array}$ \\
\hline Flexibility in use & A broad range of individual preferences and skills are accommodated in the design. \\
\hline Simple and Intuitive use & The design utilization is easy to understand regardless of users age, knowledge and experiences \\
\hline Perceptible information & $\begin{array}{l}\text { The design effectively communicates necessary information to the user, regardless of ambient } \\
\text { conditions or abilities }\end{array}$ \\
\hline Tolerance of Error & The design minimizes risks and the adverse effects of inadvertent or unintended actions \\
\hline Low Physical Effort & The playground design can be approach efficiently, comfortably with minimum of fatigue \\
\hline $\begin{array}{l}\text { Size and space for approach and } \\
\text { use }\end{array}$ & The design is appropriate for children of different body dimension, postures and abilities \\
\hline
\end{tabular}

The literature review has indicated seven universal design principle (as shown in Table 1) to enhance the chances of all children to play. Besides, the above mentioned universal design principle also emphasize the way of promoting inclusivity to both the physical environment and play equipment exist on the playground.

Table 2 : Ergonomic play

\begin{tabular}{|c|c|}
\hline Key for ergonomics play & Authors \\
\hline $\begin{array}{l}\text { Achieve fit. Proper sizing to ensure good match } \\
\text { between object and user }\end{array}$ & $\begin{array}{l}\text { (Kroemer, 2006) ; (Gonzalez and Certucha, 2019); (Grozdanovic et al., 2013) ; (Ayatac, } \\
2017) \text {; (Trocka-leszczynska et al., 2020) ; (Jafari, 2014); (Ling et al., 2019) ; (Nowakowski, } \\
\text { et al.,2007); (Levine, 1995) }\end{array}$ \\
\hline $\begin{array}{l}\text { Ensure reach where every person can properly } \\
\text { access and use the equipment or device. }\end{array}$ & $\begin{array}{l}\text { (Kroemer, 2006) ; (Gonzalez and Certucha, 2019); (Grozdanovic et al., 2013); (Petrova and } \\
\text { Sysoeva, 2018); (Ling et al., 2019); (Council, 2004); (Levine, 1995) }\end{array}$ \\
\hline $\begin{array}{l}\text { Provide secure clearance, objects do not interfere or } \\
\text { harm users }\end{array}$ & $\begin{array}{l}\text { (Kroemer, 2006) ;(Gonzalez and Certucha, 2019) ; (Majid, et al., 2015) ; (Soltani, Abbas and } \\
\text { Awang, 2012) ; (Ling et al., 2019); (Leon, 2017); (Levine, 1995) }\end{array}$ \\
\hline $\begin{array}{l}\text { Reduce entrapment hazards. Avoid the body part } \\
\text { from being trapped. }\end{array}$ & $\begin{array}{l}\text { (Kroemer, 2006) ; (Gonzalez and Certucha, 2019) ; (Majid, et al., 2015) ; (Leon, 2017) ; } \\
\text { (Shackell et al., 2013) }\end{array}$ \\
\hline $\begin{array}{l}\text { Provide barriers that separate hazardous spaces and } \\
\text { objects from all users. }\end{array}$ & (Kroemer, 2006) ; (Gonzalez and Certucha, 2019); (Majid, et al., 2015) \\
\hline
\end{tabular}

The necessities of considering ergonomics factors in play equipment are agreed by many authors in the literature review. Five main criteria have been identified in the literature review in promoting ergonomic and safe play equipment for children with all type of abilities. 


\subsection{Methodologies}

This section sets out to explain the research method used in this paper. The study focuses on the criteria of ergonomics inclusive public playground. Thus, the study pursues a qualitative approach with two research methods included; 1) physical field survey; 2) semistructured interview.

\subsection{Field survey}

The field survey was carried out in three inclusive public playgrounds located in Georgetown Penang, Titiwangsa, Kuala Lumpur and Petaling Jaya, Selangor. These three playgrounds were selected as they are the pioneers of the inclusive public playground in Malaysia. This site observation was conducted to determine the playground's current conditions, accessibility for the disabled, and others. Control lists have been developed from the literature review, including two parts: " assessment of UD concept" and "measurement of ergonomics play.' The assessment of UD is comprised of seven critical criteria, while the measurement of ergonomics play is based on five criteria listed in the literature review and also based on the existing Malaysia standard for a playground of MSS 966:2017.

\subsection{Semi-structured interviews}

The data collection follows with the semi interviews. A total of 8 participants were involved in the study, which compromises parents, caretakers, occupational therapists, and experts involved in constructing children's playground. The participant is chosen using a purposive sampling technique to ensure the respondent's credibility and the data's reliability. Each interview consisted of 30 to 60 minutes, in-depth interview sessions, and all interview sessions were digitally audio-recorded. The interviews were guided by semistructured questions used as prompts to explore and further understand the reasons behind the responses.

\subsection{Data Analysis}

During the physical field survey, all observation has been noted in the control list. Each park has also been photographed, and every playground equipment was marked in detail. The interview parts were transcribed verbatim, and content analysis has been carried out to identify key phrases.

\subsection{Limitation of Study}

The study associates with several limitations. Due to the broad scope of the topic and time constraint, the research is limited within the inclusive playgrounds managed by local authorities located in Penang, Kuala Lumpur and Selangor. Besides, the study investigated a limited type of disability where the study focuses only on children with physical disabilities.

\subsection{Result and Discussion}

\subsection{Field survey result}

\subsubsection{Current integration of UD concept}

Table 3 illustrate the data gain from the field survey. The three playgrounds' overall analysis revealed that all playgrounds did not fully comply with UD principle in the playground design. In regard to the percentage of integration of the UD principle in playground design, Playground A perceived $76.47 \%$ while Playground B and Playground C perceived $58.82 \%$ and $52.94 \%$, respectively. There are some UD principle has been violated such as simple and intuitive use, tolerance of error, low physical effort and size and space for approach and use.

\subsubsection{Measurement of Ergonomics in Play}

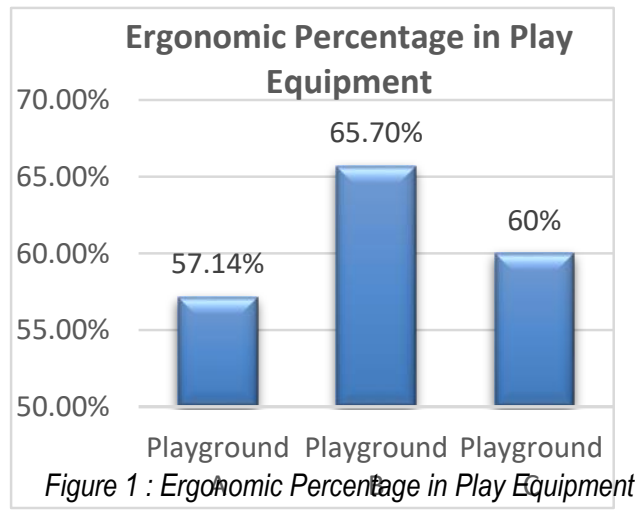

The result of the above bar graph (Figure 1) revealed that the level of compliance of the inclusive public playground in Malaysia with the existing Malaysian Standard (MS 966:2017: Playground Equipment - Safety performance for public use standard) and applicability of ergonomic principle still at the moderate quality of $57.14 \%$ to $60 \%$. There are four major concerns identified in the three playground design: accessible route, ramp for the elevated area, and transfer system and suitability of play equipment in the playground design. 
Table 3 : Integration of UD principle in inclusive public playground in Malaysia

\begin{tabular}{|c|c|c|c|}
\hline Universal Design Principle & $\begin{array}{c}\text { Playground A } \\
\text { (Youth Park } \\
\text { Accessible } \\
\text { Playground, } \\
\text { Penang) }\end{array}$ & $\begin{array}{l}\text { Playground B } \\
\text { (Taman Aman } \\
\text { Park, Petaling } \\
\text { Jaya) }\end{array}$ & $\begin{array}{c}\text { Playground C } \\
\text { (Taman Tasik } \\
\text { Titiwangsa, } \\
\text { Kuala Lumpur) }\end{array}$ \\
\hline \multicolumn{4}{|l|}{ 1. Equitable use } \\
\hline $\begin{array}{l}\text { Provide the same means of use for all users. } \\
\text { The use should be identical whenever possible, } \\
\text { or either equivalent use }\end{array}$ & $\checkmark$ & $\checkmark$ & \\
\hline No segregating or stigmatizing any users & & $\checkmark$ & $\checkmark$ \\
\hline $\begin{array}{l}\text { Provision for privacy, security and safety to all } \\
\text { user }\end{array}$ & $\checkmark$ & & $\checkmark$ \\
\hline \multicolumn{4}{|l|}{ 2. Flexibility in use } \\
\hline Diversity of option for use & $\checkmark$ & & $\checkmark$ \\
\hline Provide adaptability to the user's pace & $\sqrt{ }$ & $\checkmark$ & $\checkmark$ \\
\hline Facilitate the user's accuracy and precision & $\checkmark$ & & \\
\hline \multicolumn{4}{|l|}{ 3. Simple and intuitive use } \\
\hline No unnecessary complexity & $\checkmark$ & $\checkmark$ & \\
\hline Consistency with user expectation and intuition & $\checkmark$ & $\checkmark$ & \\
\hline Wide range of literacy and language skills & $\sqrt{ }$ & $\checkmark$ & \\
\hline \multicolumn{4}{|l|}{ 4. Perceptible information } \\
\hline Variety mode of speech (pictorial, verbal, tactile) & $\checkmark$ & $\checkmark$ & \\
\hline \multicolumn{4}{|l|}{ 5. Tolerance of error } \\
\hline $\begin{array}{l}\text { Arrangement of play equipment must be } \\
\text { accessible, not isolated or shielded }\end{array}$ & $\checkmark$ & & $\checkmark$ \\
\hline Provision of warning sign & & & $\checkmark$ \\
\hline Provision of fall surface area & $\sqrt{ }$ & & $\checkmark$ \\
\hline \multicolumn{4}{|l|}{ 6. Low physical effort } \\
\hline Help to maintain a neutral body position & $\checkmark$ & $\checkmark$ & \\
\hline Minimize repetitive action & $\checkmark$ & $\checkmark$ & \\
\hline \multicolumn{4}{|l|}{ 7. Size and space for approach and use } \\
\hline Variation in hand and grip size & & & $\checkmark$ \\
\hline $\begin{array}{l}\text { Appropriate size and space for approach and } \\
\text { reach }\end{array}$ & & $\checkmark$ & $\checkmark$ \\
\hline
\end{tabular}

\subsection{Interviews}

The analysis of the interview data has brought to the development of three essential topics. In creating an ergonomics public playground, the first essential criteria that need to be considered is the 'Play Experience.' This topic focused on the CWDs play experience on the playground and explained how parents with CWDs utilize playgrounds to help develop their children. The second topic that emerged in this study is the Playground Layout, which discussed the physical barrier faced by the CWDs while playing on the playground and the solution to the barriers. The last topic discussed in this study is 'Play Equipment, ' which focused on the usability of the current play equipment and adjustment to the play equipment to ensure the comfortability of CWDs during play.

\subsubsection{Play Experience}

The majority of the respondents emphasize the importance of play in the development of children. Especially for CWDs, play is the key learning for them, and it is a very crucial element in improving the health and emotions of CWDs. Play help to improve problem solving, creativity, imagination, social interaction and self-expression. For instance, caretakers and parents identified the benefits of experiencing movement, for example, when playing swing, walking through moving bridges, improving CWDs sensory, increasing the sense of balancing of the CWDs and improving their body posture. Playground play was referred to as "sensory-rich" in a study by Malkusak, (2002). In support of the current study, respondents sought various sensory and motor experiences when playing on the playground. In another situation, the respondents are also asked how necessary the play equipment is to be used and enjoyed by normal 
children and CWDs. $96 \%$ of the respondents' answers are important to extremely important. A mother of Cerebral Palsy children said that her child, most of the time, wants to make friends with other children but normal children attempt to distance themselves from her child. This statement support by many researchers who also agreed CWDs also faced social exclusion as these disabled children are 'essentially' different from normal children (Clarke, 2006; Connors and Stalker, 2007). However, parents who never bring their CWD to the public playground as many of the play equipment do not fit their CWD.

\subsubsection{Playground Layout}

To date, the insufficient consideration of inclusion in playground design has caused many children with disabilities to face difficulties in accessing activities in such playgrounds. This is agreed by $90 \%$ of the respondents stating that some of them only brought their CWDs to public playground two to three times in a lifetime. This explains the assertion made by Soltani, et al., (2012) stating that disabled children and their families are often not visible in communities. The situation is much more critical for those CWDs with mobility aid such as wheelchair and walking frame. Most of the respondents agreed that the design of the playground must avoid any segregating or stigmatizing to any users. For example, using stairs or ladder is not usable by everyone. Thus the need for ramps is important in promoting inclusivity. It needs to be acknowledged that these populations often face difficulty accessing playgrounds and the equipment due to their limited capabilities such as mobility and low motor skills, visual, cognitive and socio-emotional problems in interaction. Hence, removing architectural barriers needs to be done by making the playground more accessible for children with all abilities.

\subsubsection{Play equipment}

The interviews reveal that many parents and caretakers fear of lack of safety in playgrounds. For example, the absence of a protective surface on the playground may increase unwanted incidents' risk. This claim is supported by Radhi, (2018) saying that $75 \%$ of Malaysia's public playground is in bad condition. Besides, engaging disabled children in the public playground could be quite challenging as the children might utilize the play equipment in unintended and unanticipated ways. The occupational therapist also has suggested several ways to improve safety on the playground by adjusting and modifying the play equipment and highlighting ways to improve comfortability on the playground, including the necessity of tree shades, avoiding constructing playground near to water and others.

\subsection{Discussion}

The objectives of the study are successfully achieved. The data reveal that there are various inequity exist on the current design of Malaysian public playground. Although some existing public playgrounds were described as accessible,participant did not found a single fully functional playground. Following with the inductive derived themes, it believed that the integration and overlap of these three areas act as transactive components that help to opportunity to engage in social and play occupations leading to an experience of ergonomics and inclusivity. The theme of play experience and playground layout was consistent with the UD principle specifically the "equitable use" principle. While the theme play equipment is specifically point out the key for ergonomic play and way to incease play securities on the playground especially for children with disabilities.Framing the result in such way also provide the opportunities to improve the current Malaysian playground standard. Overall the claimed is supported by Law et al., (1996) stating that by improving the usability of a play space, the convergence between person and environment, it is possible to maximize the play occupation and promote inclusivity.

\subsection{Conclusion}

The study identified the current condition and usability of the public playground in Malaysia. The study data demonstrate that there are many limitations exist on the playground as the applicability of UD principle and ergonomics principle is still low. Although some existing playgrounds were described as disabled-friendly, the design still needs modification to improve inclusivity. The study also identified three crucial aspects in the development of ergonomics inclusive public playground: the play experience, playground layout, and play activities. As the current modern-day public playgrounds design does not meet children with disabilities' needs, it is advised that the public playground design must not be discriminatory and concern on children with all abilities. There is enough room for future research to study in this sensitive area. Conclusively, the result hopefully can offer helpful support to designers, city council, and many more organizations in their work to create ergonomic inclusive playgrounds, and this study also hopes that the result will subsequently uplift all children's play right significantly among children with disabilities.

\section{References}

Asyraf, F. (2019) Disabled children not registered with the Social Welfare Dept because parents embarrassed, Malaysia Kini. Available at: https://www.malaysiakini.com/news/492865 (Accessed: 5 October 2019).

Ayatac, H. (2017) 'No " Obstacles " In Playgrounds That Are Not Only Accessible But Also Inclusive', International Journal of Architecture \& Planning, 4(2), pp. 1-14. doi: 10.15320/ICONARP.2016120233.

Clarke, D. H. (2006) Preventing Social Exclusion of Disabled Children and Their Families. The United Kingdom.

Connors, C. and Stalker, K. (2007) 'Children 's experiences of disability : pointers to a social model of childhood disability', Journal of Disability \& Society, 22(1), pp. 37-41. doi: 10.1080/09687590601056162. 
Edward Elton, C. N. (2015) Inclusive Design and Design for Special Populations. Edited by S. S. J.R. Wilson. Boca Raton: CRC Press.

Feeney, R. J. and Galer, M. D. (2007) 'Ergonomics research and the disabled’, Journal of E, 24(11), pp. 37-41. doi: 10.1080/00140138108924903.

Fernelius, C. L. . (2017) Evidence- Based Practices For The Design of Inclusive Playgrounds That Support Peer Interactions Among Children With All Abilities. Utah State University.

Follette, M., James, L. and Ronald, L. (1998) The Universal Design File: Designing for People of All Ages and Abilities. Revised Ed. Washington, DC. PUB: NC State University.

Ginsburg, K. R. (2007) 'The Importance of Play in Promoting Healthy Child Development and Maintaining Strong Parent-Child', Journal of Pediatrics, 2(1), pp. 1-5. doi: 10.1542/peds.2006-2697.

Gonzalez, L. B. and Certucha, R. P. (2019) The Design of A Playground Toy. University of Skövde.

Grozdanovic, M., Jekic, S. and Stojiljkovic, E. (2013) 'Methodological framework for the ergonomic design of children 's playground equipment : A Serbian experience', Journal of Ergonomics, 14(33), pp. 1-16. doi: 10.3233/WOR-131661.

Jafari, M. (2014) Assessing Universal Design Priciple Applicaion on Children Playground at Lake Titiwangsa Park, Kuala Lumpur. Universiti Putra Malaysia.

Jing, C. C. (2019) 'Malaysians ' Attitudes toward People with Disabilities', Journal of Arts \& Social Science, 2(2), pp. $27-65$.

Law M, Cooper B, Strong S, Steward D, Rigby P, Letts L (1996). The person - environment occupation model: a transactive approach to occupation of children with physical disiabilities.Canadian Journal of Occupational Therapy, 63 (1), pp. 9- 23

Md.Saaid, A. H. (2016) Exploring Aspect of Design and Safety of Children Playgrounds in Malaysia. Universiti Sains Malaysia.

Park, K. G. V (2010) Play for All. United Kingdom

Radhi, N. A. M. (2018) 'Call For Safety Audit On Public Playgrounds To Rectify Problems And Prevent Mishaps', New Straits Times, 23 December, pp. 1-2. Available at: https://www.nst.com.my/news/nation/2018/12/443238/call-safety-audit-public-playgrounds-rectify-problems-and-prevent-mishaps

Robertson, S. . (1995) Contemporary Ergonomics 1995. Great Britain: Taylor \& Francis Ltd 1995. Available at: https://books.google.com.my/books?hl=en\&lr=\&id=515hD470VB0C\&oi=fnd\&pg=PA462\&dq=ergonomics+playground\&ots=0023u5Ng3A\&sig=meK0709sgpGVrYOmVbWkkWjmc0\&redir_esc=y\#v=onepage\&q=ergonomics playground\&f=true.

Saral James Maniam (2016) A new vision for Malaysia Playground, Malaysia Kini. Available at: https://www.malaysiakini.com/letters/327240 (Accessed: 15 September 2019).

Shea, P. and Boyle (2017) The Most Common Playground Injuries, Shea, Panish LLP, Boyle. Available at: https://www.schoolinjuryattorneys.com/contact/.

Soltani, S. H. K., Abbas, M. Y. and Awang, M. Bin (2012) 'Disabled Children in Public Playgrounds : A Pilot Study', in ASEAN Conference on Environment-Behaviour Studies, Savoy Homann Bidakara Bandung Hotel, Bandung, Indonesia. Bandung, Indonesia: y Elsevier B.V. Selection, pp. 670-676. doi: 10.1016/j.sbspro.2012.03.073.

Social Welfare Department (2019) Statistic of People with Disabilities in 2019

Team, E. (2018) UNICEF Inclusive Playground Initiative, UNICEF. Available at: https://autismmalaysia.com/2018/10/unicef-inclusive-playground-initiative/ (Accessed: 5 October 2019).

Tosi, F. (2019) Design for Ergonomics. Edited by C. Germak. Florence,Italy: Springer. 